\title{
Burden of Intestinal Parasitic Infection in a Tertiary Care Hospital
}

\author{
Ashish William*, Shweta Satija and Ravinder Kaur \\ Department of Microbiology, Lady Hardinge Medical College, New Delhi, Pin-110001, India \\ *Corresponding author
}

\begin{tabular}{|l|}
\hline Ke y w o r d s \\
$\begin{array}{l}\text { Intestinal parasitic } \\
\text { infections (IPIs), } \\
\text { Parasites, Diarrhoea }\end{array}$ \\
\hline Article Info \\
\hline $\begin{array}{l}\text { Accepted: } \\
\text { 20 June 2020 } \\
\text { Available Online: } \\
\text { 10 July } 2020\end{array}$ \\
\hline
\end{tabular}

\section{Introduction}

Intestinal Parasitic infections are endemic worldwide and are one of the major health problems in several developing countries including India. Poor Sanitation, low standards of personal hygiene, poverty, illiteracy, hot and humid tropical climate are some of the factors responsible for spread of IPIs $^{2-4}$. These infections lead to clinical morbidity in 450 million people globally ${ }^{5}$. It is seen that age and sex of general population affects the frequency of these infections ${ }^{6}$.These infections are more commonly seen amongst school age children in whom IPIs lead to nutritional deficiencies, anaemia, growth retardation and impaired learning abilities ${ }^{7-9}$. Ascaris lumbricoides, Ancylostoma duodonale, Trichuris trichura, Enterobious vermicularis, Entamoeba histolytica and Giardia lamblia are some of the common parasitic infections reported worldwide $^{3,10-11}$. Therefore, monitoring this problem from time to time and tackling it properly becomes important. 
This study was undertaken to know the prevalence of intestinal parasitic infections in patients reporting to our tertiary care hospital located at Delhi, catering to many peripheral areas of other states nearby.

The current study was aimed to determine the prevalence of intestinal parasitic infections (IPI) in patients suffering from diarrhoea.

\section{Materials and Methods}

The study was conducted in the Department of Microbiology, Lady Hardinge Medical College, New Delhi from January 2018December 2018.A total of 1872 stool samples from the patients suffering from diarrhoea attending outpatient department and indoor wards, irrespective of their age and sex status were received and processed as per physician request were included.

Samples were collected in wide mouth containers with no preservative and were transported to the laboratory within 2 hours. Naked eye physical and microscopic examination of normal saline as well as iodine preparation was carried out in each stool sample. Macroscopic examination was done for the presence of any blood, mucus, adult worm or any segments. Microscopic examination was done for presence of ova, cyst and trophozoites.

\section{Results and Discussion}

A total of 1872 stool samples were processed and studied in the present study out of which $114(6.1 \%)$ were positive either for Protozoal or Helminthic infections (Fig.1). Giardia lamblia was detected in 64(56\%) cases followed by Ascaris lumbricoides in 24(21\%) cases, and Hymenolepsis nana in 18 (15.7\%) cases. Trichuris trichura and Enterobius vermicularis were detected in $7(6 \%)$ and $1(0.8 \%$ ) cases respectively (Fig.2). A total of 974 males and 898 females included in the study showed the prevalence of parasitic infections to be nearly equal in males (49\%) and females $(51 \%)$. Prevalence was seen to be more in outpatients $90(79 \%)$ compared to inpatients 24(21\%) (Fig.3). The prevalence of parasitic infections was seen to be more in the age group 0-15 years(106 cases) compared to $>15$ years ( 8 cases)with a maximum parasite distribution in the age group of 6-10 years (64 cases) (Table 1 Fig.4). Our Study has shown the presence of parasitic infections in $114(6.1 \%)$ patients out of a total of 1872 patients. The studies carried out in various parts of India have reported different prevalence rates ranging from 6.63 to $46.7 \%{ }^{6}$, 12-13. A similar study done at our department 2 years back had showed the prevalence rate to be $10.37 \%^{14}$ (Table 2).

Table.1 Age wise Distribution of Intestinal Parasites in Tertiary Care Hospital $(n=114)$

\begin{tabular}{|l|c|c|c|c|c|}
\hline Parasites & 0-5years & 6-10years & 11-15years & $>15 y e a r s$ & Total \\
\hline Giardia lamblia & $20(31 \%)$ & $34(53 \%)$ & $5(8 \%)$ & $5(8 \%)$ & 64 \\
\hline Ascaris lumbricoides & $6(25 \%)$ & $14(59 \%)$ & $2(8 \%)$ & $2(8 \%)$ & 24 \\
\hline Hymenolepsis nana & $5(28 \%)$ & $10(56 \%)$ & $2(10 \%)$ & $1(6 \%)$ & 18 \\
\hline Trichuris trichura & $2(29 \%)$ & $5(71 \%)$ & $0(0 \%)$ & $0(0 \%)$ & 7 \\
\hline Enterobius vermicularis & $0(0 \%)$ & $1(100 \%)$ & $0(0 \%)$ & $0(0 \%)$ & 1 \\
\hline Total & 33 & 64 & 9 & 8 & 114 \\
\hline
\end{tabular}


Table.2 Comparison of Various Studies Showing Parasitic Distribution

\begin{tabular}{|c|c|c|}
\hline Authors of Various Studies & PLACE & PERCENTAGE \\
\hline $\begin{array}{l}\text { Yogita Rai, Ravinder Kaur, Gaurav Dhaka et } \\
\text { al (2017) }\end{array}$ & Delhi & $\begin{array}{l}\text { Giardia lamblia (58\%), E.histolytica } \\
(9.8 \%), \text { A.lumbricoides }(24 \%)\end{array}$ \\
\hline $\begin{array}{l}\text { Ragunathan, L.,Kalivaradhan, SK, Ramadass, } \\
\text { S, Nagaraj, M, Ramesh, K. (2010) }\end{array}$ & Puducherry & $\begin{array}{l}\text { A.lumbricoides }(43.2 \%), \text { A.duodenale } \\
(28.89 \%), \text { Trichuris trichiura }(10.8 \%) \text {, } \\
\text { H.nana }(7.6 \%), \text { Taenia spp. }(7.4 \%), \\
\text { E.vermicularis }(1.9 \%)\end{array}$ \\
\hline $\begin{array}{l}\text { Dongre, A.R.,Deshmukh, PR, Boratne, AV, } \\
\text { Thaware, P, Garg, BS(2007) }\end{array}$ & Maharashtra & $\begin{array}{l}\text { Giardia lamblia }(7.6 \%), \text { Entamoeba } \\
\text { histolytica }(4.2 \%), \text { Hymenolepis } \\
\text { nana }(2.5 \%), \text { Ascaris lumbricoides } \\
(1.7 \%), \text { Ancyclostoma duodenale } \\
(0.8 \%) \text { and Taenia }(0.8 \%)\end{array}$ \\
\hline Marothi Y, Singh B (2011) & $\begin{array}{l}\text { Ujjain, } \\
\text { MadhyaPra } \\
\text { desh, India }\end{array}$ & $\begin{array}{l}\text { Entamoeba histolytica }(10.5 \%) \\
\text { Giardia lamblia }(3.9 \%), \text { Ascaris } \\
\text { lumbricoides }(2.8 \%)\end{array}$ \\
\hline
\end{tabular}
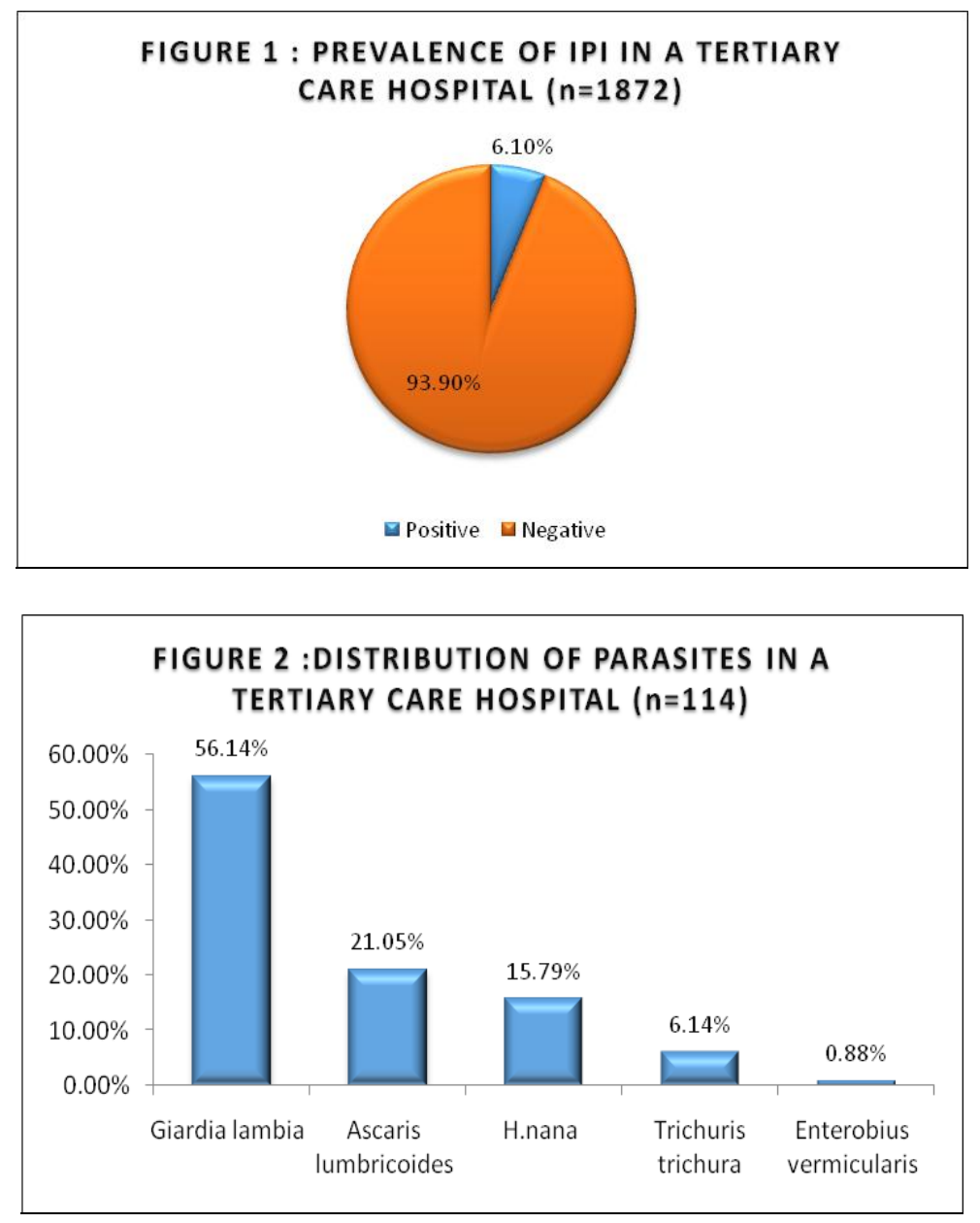
FIGURE 3 : DISTRIBUTION OF POSITIVE PATIENTS ( $n=114$ )

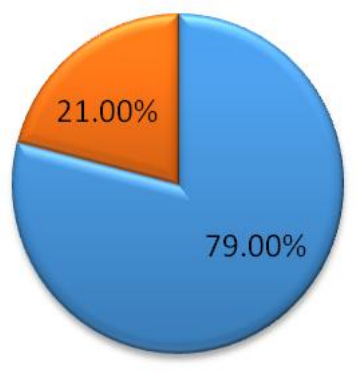

$\square$ Outpatient $\square$ Inpatients

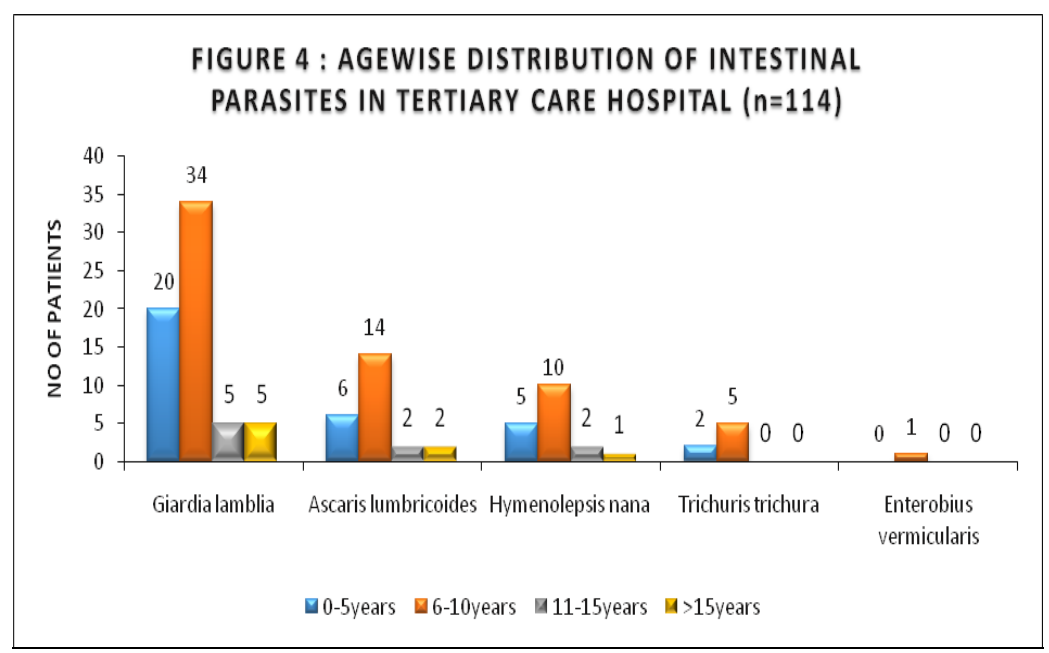

Prevalence rate of our study is on lower side suggesting better awareness of personal hygiene and environmental sanitation in the study population in the capital city of India specially showing the effects of health education and other measures taken after earlier study at the same place.

Other reason for low prevalence in our study could be that we included only symptomatic patients attending our tertiary care hospital highlighting the fact that asymptomatic carriers of IPIs might be constituting the main bulk of the global burden. We did not notice any statistically significant difference in infection rates between different sexes was found although many previous studies have reported significant differences in infection rates in the two ${ }^{6,15-16}$.
The most common parasite detected in our study was Giardia lamblia64 (56\%) amongst protozoans and Ascaris lumbricoides in 24 (21\%) amongst helminths. This finding is in accordance with many studies conducted previously in different places of the country which have shown the similar pattern ${ }^{14,17-19}$ (Table 2).

Most common age group affected was 6-10 years with $64(58 \%)$ cases followed by $0-5$ years with $33(\%)$ cases highlighting the fact that prevalence of IPIs are higher in children $^{20-22}$, who might be more exposed due to their lesser awareness.

In conclusion the present study showed the lower prevalence rate of IPIs compared to many other previous year studies in India. 
Measures for decreasing intestinal parasitic infection include: mass education on hygiene practices, improving personal and public health conditions, and large-scale de-worming campaigns, along with efforts to develop effective vaccines against major intestinal parasites would go a long way in combating these conditions and reducing morbidity due to them.

\section{References}

Alum A, Rubino JR, Ijaz MK. The global war against intestinal parasites--should we use a holistic approach? Int J Infect Dis. 2010; 732-8

AtulAher\& Sanjeev Kulkarni. Prevalence of Intestinal parasites in school going children in a rural community. Int $\mathrm{J}$ Biomed Research. 2011; 2(12): 605-7.

Awasthi, S., \& Pande, V. K. 1997). Prevalence of malnutrition and intestinal parasites in preschool slum children in Lucknow. Indian Pediatr. 1997; 34:599-605.

Bansal D, Sehgal, R., Bhatti, H. S., Shrivastava, S.K., Khurana, S., Mahajan, R. C., \& Malla, N. Intestinal parasites and intra familial incidence in a low socio-economic area of Chandigarh (North India). Nepal Med Coll J. 2004; 6:28-31.

Baragundi MC, Sonth SB, Solabannwar S, Patil CS. The prevalence of parasitic infections attending tertiary care Hospital. National $\mathbf{J}$ of Basic Medical Science. 2011; 2(1): 31-4.

Bora D, Meena VR., Bhagat H. et al., Soil transmitted helminthes: Prevalance in school children of Pauri Gharwal district, Uttaranchal State. J commune Dis. 2006; 38: 112-4

Davane MS, Suryawanshi NM, Deshpande KD. A prevalence study of Intestinal parasitic INFECTIONS IN Rural Hospital. IntJ Recent trends in Science
\& Technology.2012; 2(1):1-3.

Dongre, A.R., Deshmukh, PR, Boratne, AV, Thaware, P, Garg, BS. Anapproachtohygiene education among rural Indian school going children. Online JHealth Allied Sci. 2007; 6:1-6.

Eatson A. Intestinal worm impair child health in the Philippines. BMJ. 1999; 318: 214.

Ghanshyam Kavathia, Manish Pattani, Milan Dharsandiya et al., A prevalence study of intestinal parasitic infections in a tertiary care hospital in Rajkot city of Gujrat (India): A Hospital based study. J of Dental \& Medical Sciences. 2015; 14(10): 45-7.

Ibrahim AH. Prevalence of Intestinal parasites among school children in Dier-ELBalah town in Gaza strip, Palestine. Ann Saudi Med. 2002; 22(3-4): 273-5.

Kang G., Mathew MS., Rajan DP, et al., Prevalence of Intestinal parasites in rural southern Indians. Tropical Med Int Health. 1998; 3(1):70-5.

Marothi Y, Singh B. Prevalence of intestinal parasites at Ujjain, Madhya Pradesh, India: Five-year study. AfrJ Microbiol Res. 2011; 5: 2711-4.

MisraShobha, DuttaroyBithika, Shroff Bhavesh. The prevalence of Intestinal parasitic infections in the urban slums of acity in western India. $\mathrm{J}$ of Infection \& Public health. 2013; 6: 142-9.

Ragunathan, L.,Kalivaradhan SK,Ramadass S, Nagaraj, M, Ramesh, K. Helminthic infections in school children in Puducherry, South India. J Microbiol Immunol Infect. 2010; 43: 228-32.

Saki J., Khademvatan S., et al., Prevalence of Intestinal parasitic infections in haftel county, southwest of Iran. Int J Infect. 2017; 4(\$):15593

Sehgal R, Gogulamudi V. Reddy, Jaco J. Verweij et al., Prevalence of Intestinal parasitic infections among school children and pregnant women in a low 
socio economic area, Chandigarh. North India.Reviews in infection. 2010; 1(2):100-3.

Singh C, Zargar SA, Masoodi I, et al., Predictors of Intestinal Parasitosis in school children of Kashmir: a prospective study. Tropical Gastroenterol. 2010; 31(2): 105-7.

Singh DS., Chandani RR, Kumar S et al., revelance\& pattern of Intestinal parasitism: A rural community of Varanasi. Ind J Pre Soc Med.1984; $15: 1-8$

Wani SA., Ahmed F, Zargar SA et al.Prevalence of Intestinal parasites and associated risk factors among school children in Srinagar city, Kashmir. J Parasitology. 2007; 93(6): 1541-3.

Yogita Rai, Ravinder Kaur, Gaurav Dhaka et al., Spectrum of Intestinal parasitic infections in Pediatric population in atertiary care hospital. Int J CurrMicrobiol App Sci. 2017; 6(10): 179-83.

YogyataMarothi \& Binita Singh. Prevalence of Intestinal parasites at UJJAIN, Madhya Pradesh, India: Five Year Study. African J Microbiol Research. 2011; 5(18): 2711-4.

\section{How to cite this article:}

Ashish William, Shweta Satija and Ravinder Kaur. 2020. Burden of Intestinal Parasitic Infection in a Tertiary Care Hospital. Int.J.Curr.Microbiol.App.Sci. 9(07): 2542-2547. doi: https://doi.org/10.20546/ijcmas.2020.907.298 